\title{
Regional phytogeographic analysis of the flora of the Mounts of Saida (western Algeria): evaluation-restoration report
}

\author{
Sid Ahmed Aouadj ${ }^{*}$, Yahia Nasrallah² \& Okkacha Hasnaoui' \\ 'Laboratory of Ecology and Management of Natural Ecosystems, Department of Ecology and Environment, Faculty of Nature and \\ Life Sciences and Earth and Universe Sciences, Abou Bakr Belkaid University, Tlemcen, Algeria \\ ${ }^{2}$ Laboratory of Biotoxicology, Pharmacognosia and Biological Valuation of Plants, Department of Biology, Faculty of Science, \\ Universeity of Dr. Tahar Moulay, Saida, Algeria \\ *Corresponding author, email: sidahmedaouadj@yahoo.com
}

ABSTRACT

\begin{abstract}
A regional floristic and phytogeographic study was conducted in the Mounts of Saida, a subsector of the Tell Atlas (Oran) (O3), in the western Algeria. On an area of $56.31 \mathrm{Km}^{2}$ surveyed regularly over time during the springs and autumns from 2017 to 2019. A total of 344 taxa divided into 77 families and 223 genera, including 18 new (exogenous) for Tell Atlas (Oran) sub-sector (O3), have been inventoried. Of these 18 species, 8 belong to the phytogeographic areas of the arid (H) and hyperarid (AS) regions and 2 invasive species that reinforce and confirm theories of plant dispersal to the north and to high altitudes for adapting to climate change. The Factor Analysis of Correspondences (F.A.C) shows that species distribution is the result of local microclimates associated with the elevation; particularly, the mountains facing north receive a significant amount of humidity from the Mediterranean Sea.
\end{abstract}

KEY WORDS Analysis; climate change; Dispersal; Mounts of Saida; Regional phytogeographic.

Received 18.09.2019; accepted 15.02.2020; published online 25.02.2020

\section{INTRODUCTION}

Phytogeographic and Chorological studies are a very important basis for any conservation and restoration attempt of the local flora (Quezel, 1999). They allow us to know the natural history of a given region and they are a true model for interpreting the phenomena of ambiental regression (Olivier et al., 1995).

According to Molinier (1934), two points of view remain attached to this distribution: 1) how a particular species live in a specific habitat and if it can be introduced in another region; 2) how the flora has developed itself and its behavior towards local ecological factors in a region over time, con- sidering that the conditions of the environment changes through the ages.

The floristic sectors and subsectors subdivision is a reflection of the narrow climate-vegetation dependence based on the phytogeographic division of Barry et al. (1974).

Among these, there are phenomena of regression and global warming at the regional level.

The effect of climate change on biodiversity in general, including vegetation, has been and continues to be the subject of interest to several authors, including Singh \& Wheaton (1991), Brooks et al. (1998), Hebda (1998), Thompson et al. (1998), Hansen \& Dale (2001), Li et al. (2000), Kirschbaum (2000), Malcolm et al. (2002), Chuine 
et al. (2004), Callaghan et al. (2005), Gray (2005), Juday et al. (2005), Usher et al. (2005), Hamman \& Wang (2006), Mckenney et al. (2007) and Aitken et al. (2008).

As the climate changes occur, some animal and plant species may evolve to adapt to new environmental conditions, while others may move their range to areas and regions that are more suited for their survival, for example, high altitudes. Such a phenomenon of displacement, known as "dispersal", is an important natural adaptation mechanism. In this context, Callaghan et al. (2005) report that "The expected increase in temperatures will increase plant productivity and change the range of floristic species. More widespread species will see their range expand northward with greater abundance and species exclusive or mainly those from higher latitudes will see their ecological niche shrink. The latitude and amount of light will limit the northward migration of some plant species despite rising temperatures. The cumulative effects of climate change on certain factors are likely to lead to the emergence of new phytocenoses, with different taxonomic structures and compositions".

Usher et al. (2005) report that: "Climate change should affect biodiversity by changing species range and habitats, species abundance, genetic diversity and species behavior migratory species and the introduction of exotic species".

To summarize: climate change will produce new ecological niches that will encourage the emergence of new species on a given site. For the majority of species, climate-friendly biotopes will move northwards and will rise at high altitudes. The range of species adapted to hot and dry climates will extend to areas that are currently occupied by species better adapted to cool climates and, therefore, there will be changes in floristic composition, species distribution, age class distribution and ecosystem structure.

The Mounts of Saida belong to the Holarctic Empire, the Mediterranean region, the EuMediterranean sub-region, Mediterranean Maghrebian domain, the Oran sector $(\mathrm{O})$ and the Tell Atlas (Oran) subsector (O3) (Quézel \& Santa, 1962-1963).

The first research in western Algeria was that of Babali et al. (2014) in the Tlemcen region. This work shows the emergence of 9 new plant species (exogenous) for O3, but which have been observed in other biogeographical sectors including arid and hyperarid regions.

The objective of this study is to contribute, in addition to the aforementioned study (Babali et al., 2014), with the proposal for a new list of the flora of Tell Atlas (Oran) subsector (O3) with a complete inventory of plants and on the basis of literature data (Quézel \& Santa, 1962-1963).

\section{MATERIAL AND METHODS}

\section{Study area}

The natural forests of Doui Thabet located to the west of the mounts of Saida are part of the biogeographic subsector of the Tell Atlas (Oran) (O3). They cover an area of $56.31 \mathrm{Km}^{2}$ (Fig. 1). She is characterized by a semi-arid climate where the average annual rain fall range from $300 \mathrm{~mm}$ to 350 $\mathrm{mm}$. January is the coldest month with a minimum of $2^{\circ} \mathrm{C}$, and the warmest month, with maximum averages of $35^{\circ} \mathrm{C}$. The area is characterized by a dry and warm period from April to October, and another rainy and cold from November to March.

According to the numerical model of the terrain (N.M.T), the area has a very heterogeneous and rugged terrain, its altitude is between $580 \mathrm{~m}$ and $1203 \mathrm{~m}$.

\section{Methods}

The principle of this work is based mainly on

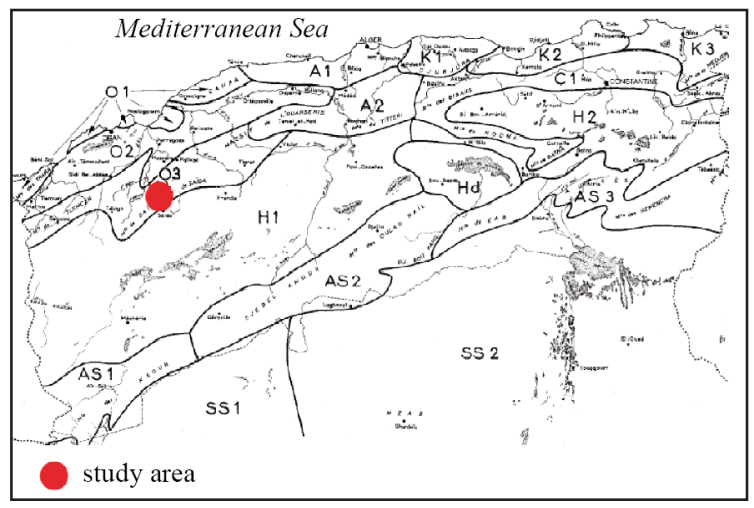

Figure 1. Location of the study area in the map of the main biogeographical territories of Algeria (Quézel \& Santa, 1962-1963) 
the comparison of data between our floristic inventory and the bibliographical data of taxa listed in the work on the Tell Atlas (Oran) (O3) of Quézel \& Santa (1962-1963).

The type of sampling adopted in this work, called 'mixed', combines a stratified sampling to designate homogeneous ecological zones, followed by a sampling for the choice of stations inside of these areas during spring and autumn from 2017 to 2019 (some species are autumn-flowering, others early flowering and others late).

The determination of the main homo-ecological zones is carried out on the basis of integration of maps of different stratifiers such as altitude, slope, soil type, exposure, substrate, and vegetation physiognomy, in the Geographic Information System (G.I.S). Regarding topographic stratifiers, we have developed a digital field model (M.N.T) from a radar image by the software Mapinfo then extracted the cards altitudes, slopes, and exhibitions. For other stratifiers, we used the lithologice map (B.N.E.D.E.R, 1992), the geological units map of the study area (S.A.T.E.C, 1976) and the map of plant formations (B.N.E.D.E.A, 1992).

The cross of data was done by the following function:

$$
\frac{1}{N} \times \sum\left(A_{i}+B_{i}+C_{i}+D_{i}+E_{i}+F_{i}\right)
$$

$\mathrm{N}$ : number of parameters used in model $=6 ; \mathrm{A}$ : pixel information in parameter a (substrates); B: pixel information of parameter $b$ (type of soil); $C$ : the pixel information of the parameter $\mathrm{c}$ (physionomy); D: the pixel information of the parameter D (altitude); E: pixel information for the parameter $\mathrm{E}$ (slope); F: the pixel information of the parameter $\mathrm{F}$ (exposure).

323 phytoecological surveys spread over the 7 zones covering our entire study area were carried out on ace surfs that were remarkably homogeneous. The minimum area retained is $100 \mathrm{~m}^{2}$ containing almost all of the species present (Braun-Blanquet, 1932).

The botanical identification of taxa was made at Laboratory of Ecology and Management of the Natural Ecosystems, Aboubakr Belkaid University (Tlemcen) using the works of Quézel \& Santa (1962-1963) to determine the regional range (bio- geographic distribution) and Dobignard \& Chatelain (2010-2013) to update the flora.

The Factor Analysis of Correspondences (F.A.C) allows us to search for the affinities that exist between species and/or surveys (taxa data, coded in the presence-absence) in order to determine ecological factors that influence the distribution of these 18 taxa at prospected stations. The hierarchical ascending classification (H.A.C) is used to determine plant groups. The analyses were performed using XLSTAT software.

\section{RESULTS}

Following the overlay of the various maps and field surveys, we have cleared seven ecological zones (Table 1).

The floristic inventory of the study area allowed us to list 344 taxa divided into 77 families and 223 genera of which we discovered 18 taxa not already observed in the biogeographic subsector O3 (Table $2,3)$.

The distribution of the 18 taxa at the seven stations in the study area is heterogeneous according to environmental variables (including rugged terrain and a mixture of various plant species) (Fig. 2).

The abundance of these taxa is divided as follows: Atractylis humilis subsp. caespitosa has the largest abundance (339 specimens), Quercus faginea (113 specimens), Artemisia herba alba (93 specimens), Carduncellus pinnatus (73 specimens), Centaurea acaulis subsp. boissieri (61 specimens), Clematis cirrhosa (51 specimens), Thymelaea virescens (46 specimens), Retama retam (47 specimens), Anacyclus valentinus (32 specimens), Crithmum maritimum (30 specimens), Echium confusum (19 specimens), Helianthemum pomeridianum and Salvia argentea subsp. patula (14 specimens), Ailanthus altissima (11 specimens), Scrofularia hypericifolia (7 specimens), Iris unguicularis (6 specimens) and Fraxinus augostifolia and Laurus nobilis (4 specimens) (Fig. 3).

The dendrogram of hierarchical ascendant classification (HAC), applied to these taxa, shows that the 18 taxa are divided into three main groups (Fig. 4).

The group "A" is made up of Artemisia herba alba, Atractylis humilis subsp. caespitosa, Centau- 
rea acaulis subsp. boissieri, Helianthemum pomeridianum, Retama retam, Scrofularia hypericifolia, Thymelaea virescens.

The group " $\mathrm{B}$ " is made up of Clematis cirrhosa, Crithmum maritimum, Iris unguicularis, Anacyclus valentinus and Salvia argentea subsp. patula.

The group " $\mathrm{C}$ " is made up of Ailanthus altissima, Carduncellus pinnatus, Echium confusum, Fraxinus augostifolia, Laurus nobilis and Quercus faginea.

The study of the distribution of species and points surveyed points (FAC) (Fig. 5) shows that axis 1 , which expresses $33.51 \%$ of the total variance, opposes on both sides of the origin the contributing species linked to plant formations located in low altitudes (T13, T14 and T15) to those highaltitude plant formations. This axis seems to reflect an ecological gradient linked to altitude. This gradient would be associated with the amount of precipitation and temperature.
Axis 2, which accounts for $18.65 \%$ of variance, also contrasts species of plant formations located in a northern geographical position with those in a southern geographical position (T15). This axis seems to express an ecological gradient linked to the physionomic type of plant formations, from clear herbaceous and champhyte formations to degraded woody formations (R39). This gradient would be associated with the impact of anthropogenic pressure on natural forest formations, overgrazing, clearing and especially repeated fires.

\section{DISCUSSION}

It is clear from this work that the area of Doui Thebet is characterized by a remarkable floristic diversity. The specific richness is 344 plant species equal to $9.18 \%$ of Algeria's flora (3744 taxa) (Do-

\begin{tabular}{|c|c|c|c|c|c|}
\hline \multirow{2}{*}{ Zone } & \multicolumn{5}{|c|}{ Ecological conditions } \\
\hline & Biotope & $\begin{array}{l}\text { Elevation } \\
\quad(\mathrm{m})\end{array}$ & Position & $\begin{array}{c}\text { Slope } \\
(\%)\end{array}$ & Soil \\
\hline 1 & Scrub: Pinus halepensis Miller & $900-1203$ & $\begin{array}{l}\text { Northwest to } \\
\text { Northeast }\end{array}$ & $0-6$ & $\begin{array}{l}\text { red brown, } \\
\text { sanded- } \\
\text { textured soils }\end{array}$ \\
\hline 2 & Riverine & $580-600$ & $\begin{array}{l}\text { Northwest to } \\
\text { Northeast }\end{array}$ & $0-3$ & $\begin{array}{l}\text { light-textured } \\
\text { red brown soils }\end{array}$ \\
\hline 3 & Scrub: Tetraclinis articulata (Vahl) Masters & $720-897$ & South & $3-11$ & $\begin{array}{l}\text { Limestone } \\
\text { brown soil }\end{array}$ \\
\hline 4 & $\begin{array}{l}\text { Scrub: Olea europaea L. and } \\
\text { Pistacia lentiscus L. }\end{array}$ & $900-1150$ & Northeast & $\geq 12$ & Lithosol \\
\hline 5 & $\begin{array}{l}\text { Scrub: Tetraclinis articulata (Vahl) } \\
\text { Masters and Juniperus oxycedrus L. }\end{array}$ & $900-1000$ & South & $3-10$ & $\begin{array}{l}\text { red-brown } \\
\text { soils with } \\
\text { humiferous }\end{array}$ \\
\hline 6 & Scrub: Cistus L. & $800-950$ & $\begin{array}{l}\text { Northwest to } \\
\text { Northeast }\end{array}$ & $0-4$ & $\begin{array}{l}\text { red brown, } \\
\text { sanded- } \\
\text { textured soils }\end{array}$ \\
\hline 7 & $\begin{array}{l}\text { Scrub: Rosmarinus officinalis L. and } \\
\text { Lavandula stoechas L. }\end{array}$ & $850-989$ & Flat & $0-5$ & $\begin{array}{l}\text { red brown, } \\
\text { sanded- } \\
\text { textured soils }\end{array}$ \\
\hline
\end{tabular}

Table 1. Characterization of stations sampled in the study area. 


\begin{tabular}{|c|c|c|c|}
\hline Family & Number of specics & Family & Number of species \\
\hline Aizoaccac & 1 & Linaccac & 2 \\
\hline Alliaceae & 1 & Lythraceae & 1 \\
\hline Anacardiaceae & 4 & Malvaceae & 3 \\
\hline Araceae & 1 & Moraceae & 1 \\
\hline Arecaceae & 1 & Myritaceae & 1 \\
\hline Araliaceae & 1 & Neuradaceae & 1 \\
\hline Asteraceae & 60 & Oleaceae & 5 \\
\hline Asparagaccac & 3 & Orchidaccac & 4 \\
\hline Asphodelaceae & 1 & Orobanchaceae & 2 \\
\hline Aspleniaceae & 2 & Oxalidaceae & 1 \\
\hline Apiaceae & 16 & Papaveraceae & 3 \\
\hline Apocynaccac & 1 & Pinaccac & 1 \\
\hline Boraginaceae & 4 & Plantaginaceae & 4 \\
\hline Brassicaceae & 20 & Poaceae & 13 \\
\hline Capparaceae & 1 & Polygalaceae & 1 \\
\hline Caprifoliaceae & 1 & Polygonaceae & 3 \\
\hline Caryophyllaceae & 5 & Primulaceae & 3 \\
\hline Cistaceae & 10 & Pteridaceae & 2 \\
\hline Colchicaceae & 1 & Rafllesiaceae & 1 \\
\hline Convolvulaceae & 3 & Ranunculaceae & 9 \\
\hline Cupressaceae & 3 & Resedaceae & 2 \\
\hline Cucurbitaceae & 1 & Rhamnaceae & 2 \\
\hline Crassulaccac & 7 & Rosaccac & 4 \\
\hline Dipsacaceae & 2 & Rubiaceae & 5 \\
\hline Ericaceae & 2 & Ruscaceae & 1 \\
\hline Euphorbiaceae & 2 & Rutaceae & 2 \\
\hline Fabaccac & 42 & Salicaccac & 2 \\
\hline Fagaceae & 3 & Santalaceae & 1 \\
\hline Frankeniaceae & 1 & Scrophulariaceae & 3 \\
\hline Gentianaceae & 2 & Sinopteridaceae & 1 \\
\hline Geraniaceae & 4 & Simaroubaceae & 1 \\
\hline Globulariaceae & 1 & Smilacaceae & 1 \\
\hline Hyacinthaceae & 4 & Solanaceae & 2 \\
\hline Illccebraccac & 1 & Tamariaccac & 1 \\
\hline Iridaceae & 5 & Thymelaeceae & 3 \\
\hline Juncaceac & 1 & Urticaccac & 2 \\
\hline Lauraceae & 1 & Valerianaceae & 1 \\
\hline Lamiaceae & 27 & Zygophyllaceae & 1 \\
\hline Liliaceae & 2 & / & $/$ \\
\hline
\end{tabular}

Table 2. Number of species by family. 


\begin{tabular}{|c|c|c|c|}
\hline $\mathbf{N}^{\circ}$ & Taxa & $\begin{array}{l}\text { Biogeographic distribution } \\
\text { (Quézel \& Santa 1962-1963) }\end{array}$ & Station \\
\hline 1 & Ailanthus altissima (Mill.) Swingle & Invasive & 3 \\
\hline 2 & Artemisia herba-alba Asso & CCC: H1-2, SS1-2 & $1,3,6,7$ \\
\hline 3 & Atractylis humilis subsp. caespitosa (Desf.) Maire & $\mathrm{CC}: \mathrm{H} 1-2, \mathrm{AS} 1-2$ & $1,3,6,7$ \\
\hline 4 & Carduncellus pinnatus (Desf.) DC & R: KI: Djurdjura, A2: 01-3, H1-2 & 6 \\
\hline 5 & Centaurea acaulis subsp. boissieri Maire & $\mathrm{C} 1$ & $1,3,6,7$ \\
\hline 6 & Clematis cirrhosa $\mathrm{L}$. & C: Coastal area, R: Elsewhere & $2,4,6$ \\
\hline 7 & Crithmum maritimum $\mathrm{L}$. & $\mathrm{CC}$ & $2,4,6$ \\
\hline 8 & Echium confusum Coincy & CC: Coastal area & 2,6 \\
\hline 9 & Fraxinus angustifolia Vahl & Invasive & 1 \\
\hline 10 & Helianthemum pomeridianum Dunal & $\begin{array}{l}\text { CCC: O1, Coastal area: Oran, } \\
\text { O2: Coastal plains subsector }\end{array}$ & $1,3,6$ \\
\hline 11 & Laurus nobilis $\mathrm{L}$. & AC: Tell Constantinois and Algerians & 1 \\
\hline 12 & Quercus faginea Lam. & $\begin{array}{l}\text { AC: in the forests of the Tell } \\
\text { mountains east of Algiers }\end{array}$ & 1 \\
\hline 13 & Retama raetam (Forssk.) Webb. \& Berthel & C: Hd. AS1-2, H1-2. SS1-2, SO & $1,3,6,7$ \\
\hline 14 & Scrophularia hypericifolia Sprengel & CC: SS1-2, Hd & $1,3,6,7$ \\
\hline 15 & Thymelaea virescens Meisn. & Arid region & $1,3,5,7$ \\
\hline 16 & Iris unguicularis Poir. & CC: Tell Constantinois and Algerians & 4 et 6 \\
\hline 17 & Anacyclus valentinus $\mathrm{L}$. & AC: $\mathrm{H} 1, \mathrm{AS} 1, \mathrm{SS} 1-2$. & $1,2,4,6$ \\
\hline 18 & Salvia argentea subsp. patula $=$ Salvia patula $\mathrm{L}$. & $\mathrm{C}: \mathrm{H} 1-2$ & 4,6 \\
\hline
\end{tabular}

Table 3. New species for the flora of the Tell Atlas (Oran) sub-sector (O3). 
bignard \& Chatelain, 2010-2013). These species belong to 223 genera and 77 families; of these, 8 families clearly dominate the flora of the area of Doui Thabet. These families, recognized by their acclimatization to the aridity of the climate of the area, are: Asteraceae ( 60 species equal to $17.44 \%$ ), Fabaceae (42 species equal to $12.20 \%$ ), Lamiaceae (27 species equal to $7.84 \%$ ), Brassicaceae (20 species equal to $81 \%$ ), Apiaceae (16 species equal to $4.65 \%$ ), Poaceae (13 species equal to $3.77 \%$ ), Cistaceae (10 species equal to $2.90 \%$ ) and Ranunculaceae ( 9 species equal to $61 \%$ ). They alone total 197 species, or $57.26 \%$ of the total; the other 69 families contribute to the $42.74 \%$ of the total.

This result is different from that obtained by Djebbouri \& Terras (2019) in a work on floristic diversity with particular reference to endemic, rare, or endangered flora in forest formations of Saida
(Algeria). They did not find 16 families and 27 non-common families or 35 species: Alliaceae (1 taxon), Araceae (1 taxon), Araliaceae (1 taxa), Asphodelaceae (1 taxon), Capparaceae (1 taxon), Colchicaceae (1 taxon), Dipsacaceae (2 taxa), Frankeniaceae (1 taxon), Gentianaceae (2 taxa), Globulariaceae (1 taxon), Hyacinthaceae (4 taxa), Illecebraceae (1 taxon), Juncaceae (1 taxon), Lauraceae (1 taxon), Lythraceae (1 taxon), Neuradaceae (1 taxon), Rafflesiaceae (1 taxon), Rhamnaceae (2 taxa), Ruscaceae (1 taxon), Salicaceae (2 taxa), Santalaceae (1 taxon), Sinopteridaceae (1 taxon), Simaroubaceae (1 taxon), Solanaceae (2 taxa), Tamariaceae (1 taxon), Valerianaceae (1 taxon) et Zygophyllaceae (1 taxon).

This difference in results can be explained by: research limited, the duration of the surveys, the sampling techniques used.

The hierarchical classification shows that there

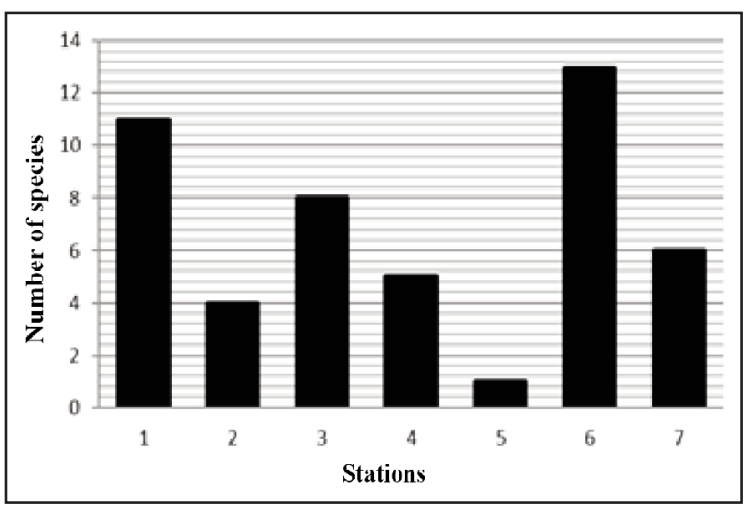

Figure 2. Number of species recorded in each area.

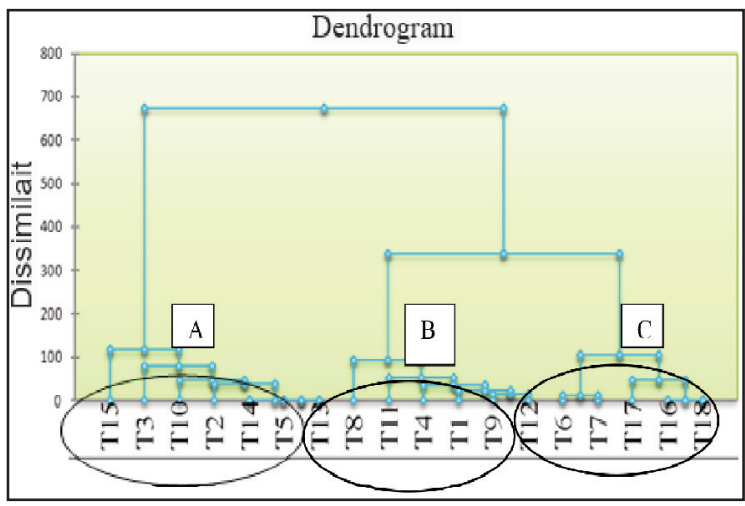

Figure 4. Ordination of hierarchical ascendant classification (HAC).

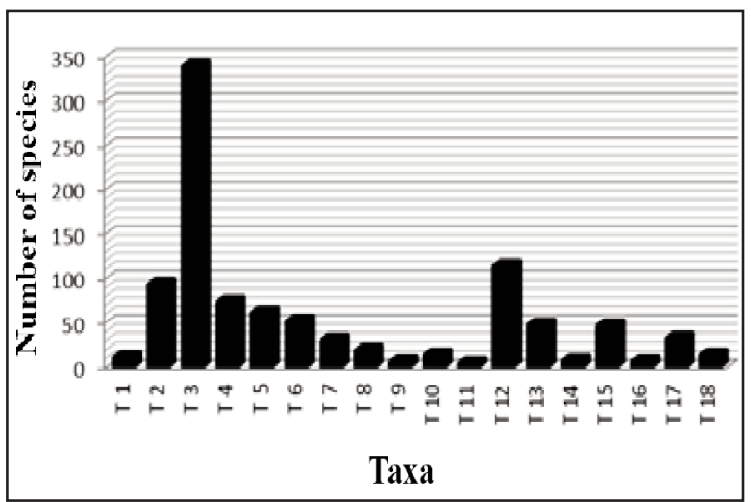

Figure 3. Abundance of each taxon.

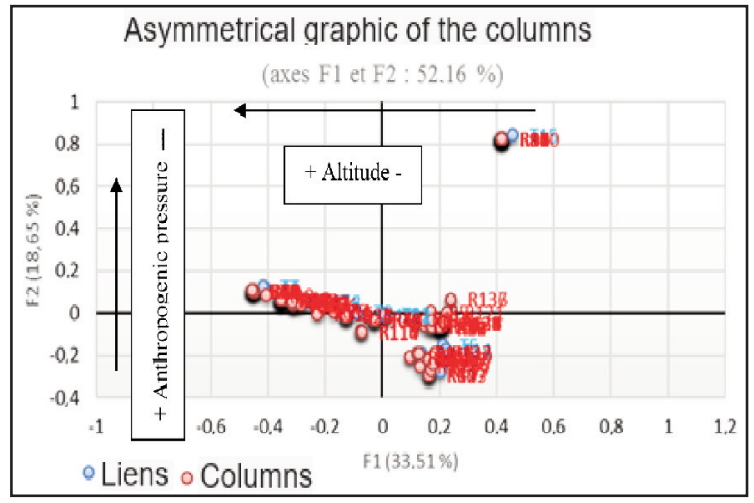

Figure 5. Ordination of the Factor Analysis of Correspondences (FAC). 
are three groups divided as follows: the first concerns xerophilic species from the arid and hyperarid regions of the sectors and subsectors $(\mathrm{H}, \mathrm{SO}, \mathrm{SS} 1-$ 2, AS1-2-3 and SC), the second areas of well-watered areas and the coastline of two sub-sectors (O1: Coastal Sahel subsector and O2: Coastal Plains Subsector), the third relates to invasive species disturbance of the environment (see Quézel \& Santa, 1962-1963) and the eastern region which is characterized by a humid and subhumid climate thanks to the high altitudes of Tell Atlas.

The appearance of Thymelaea virescens, Artemisia herba-alba, Atractylis humilis subsp. caespitos, Retama retam, Carduncellus pinnatus, Scrofularia hypericifolia, Salvia argentea subsp. patula and Anacyclus valentinus at the level of our study area is justified by the refuge of these species of origin from the area sigh plateaus $(\mathrm{H})$, Saharan Atlas (AS), Sahara Central (SC), Hodna Subsector (Hd), Western Subsector of The Northern Sahara (SS1), Eastern Subsector of the Northern Sahara (SS2) and Western Sahara Sector (SO), which is characterized by an arid and hyperarid climate to the north (our semi-arid climate study area) as a mechanism for adapting to climate change. A similar result was observed by Babali et al. (2014) in the Moutas-Tlemcen Game Reserve which shows the refuge of 9 exogenous plant species from the (O3) to the north: Anacyclus valentinus : (H1, AS1, SS. A: SC), Centaurea acaulis subsp. balansae (R and R.) M: (Constantinois), Atractylis humilis subsp. caespitosa (Desf.) M. (H, AS), Diplotaxis harra: (H1-2, AS1-2-3, SS: Up to mouydir), Ophrys subfusca: (K3, C1, K1, Al-2, O: Mostaganem), Pituranthos scoparius: (H1-2, AS1-2-3, SS, SC, SO), Ranunculus gramineus: (H1-2. AS1-2-3), Salvia argentea subsp. patula: (H1-2: Mountains), Thymelaea argentata $=T$. nitida Desf:: (H1-2) to the North.

These results are consistent with these of Maire (1952), Singh \& Wheaton (1991), Brooks et al. (1998), Hebda (1998), Thompson et al., (1998), Hansen \& Dale (2001), Li et al. (2000), Kirschbaum (2000), Malcolm et al. (2002), Chuine et al. (2004), Callaghan et al. (2005), Gray (2005), Juday et al. (2005), Usher et al. (2005), Hamman \& Wang (2006), Mckenney et al. (2007) and Aitken et al. (2008).

The presence of all these species in our study area is explained by the existence of local microcli- mates at high altitudes (1203 meters) and on the northern slopes of the mountains which receives a significant amount of moisture from the Mediterranean Sea.

Regarding the two invasive species, their presence indicates two things: 1) this area is in a state of disturbance due to human actions and especially the repeated fires at Station 1 (El Ache) and 3 (Oum Touadjine) during the period of 1992-2015, this result is consistent with the mention of Quézel \& Santa (1962-1963): "Ailanthus altissima (Mill.) develops in disturbed areas"; 2) climate change is expected to affect the introduction of exotic species (Usher et al., 2005).

Regarding Quercus faginea, 113 natural relics were found; the average height of these specimens varied between 15-18 meters. Usually, they are found in high cliffs and, in some cases, also in the wadis. A study on the ancient flora is necessary because Quézel \& Santa (1962-1963) did not mention the presence of this species and Laurus nobilis in this area.

\section{CONCLUSIONS}

Due to its geographical location, the vascular flora of the Thabet area is rich and diverse with 344 taxa, which reinforces the interest for the protection and conservation of this floristic diversity.

This work highlights the change in the distribution of flora at the regional level by the appearance and emergence of new plant species ( 8 species) in this subsector $\mathrm{O} 3$ observed in the phytogeographic areas of the climate arid and hyperarid and by the introduction of two exotic species indicator of ecosystem disturbance. The other species are the result of microclimates linked to the elevation, to streams presence and the northern position of the mountains that receive a significant amount of moisture Mediterranean Sea.

\section{ACKNOWLEDGEMENTS}

The author would like to thank Pr. Mohamed Ibn Tattou (Mohammed VI University, Rabat-Morocco), Dr. Boumediene Medjahdi (Abi Bakr Belkaid University, Tlemcen-Algeria) and Dr. Hadj Khatir (Veterinarian - Canada). 


\section{REFERENCES}

Aitken S.N., Yeaman S., Holliday J.A., Wang T. \& Curtis-Mclane S., 2008. Adaptation, migration or extirpation: climate change outcomes for tree species. Evolutionary Applications, 11: 95-111. https://doi. org/10.1111/j.1752-4571.2007.00013.x.

Babali B., 2014. Contribution à une étude phytoécologique des monts de Moutas (Tlemcen-Algérie occidentale): Aspects syntaxonomique, biogéographique et dynamique. Thése Doctorat Université de Tlemcen, $160 \mathrm{pp}$.

Barry J.P, Celles J.C. \& Faurel L., 1974. Carte international du tapis végétal, 1/1000000. Alger, 1 carte.

B.N.E.D.E.R., 1992. Etude du développement agricole dans la wilaya de Saida. Rapport final et documents annexes, $297 \mathrm{pp}$.

Braun-Blanquet J., 1932. Plant sociology: the study of plant communities. Mc Graw Hill, New York. https: //doi.org/10.5962/bhl.title.7161

Brooks J.R., Flanagan L.B. \& Ehleringer J.R., 1998. Responses of boreal conifers to climate fluctuations: indications from tree-ring widths and carbon isotope analyses. Canadian Journal of Forest Research, 8: 524-533. https://doi.org/10.1139/cjfr-28-4-524

Callaghan T.V., Björn L.O., Chapin S., Chernov Y., Christensen T.R., Huntley B., Ims R., Johanson M., Riedlinger D.J., Matveyeva N., Oechel W., Panikov N. \& Shaver G., 2005. Arctic Tundra and Polar Desert Ecosystems In Arctic Climate Impact Assessment, Cambridge University Press, Londres, 243-352.

Chuine I., Thuiller W. \& Morin X., 2004. Impacts of climate change on populations and species distributions. Pages 1-6 en G.A. O’Neill \& J.D. Simpson, éditeurs. 2004. Climate change and forest genetics. Proceedings 29th Meeting Canadian Tree Improvement Association, Kelowna (C.B.), 26-29 juillet 2004. <http: //dsppsd.pwgsc.gc.ca/Collection/Fo1-16-2004E2. pdf $>$

Djebbouri M. \& Terras M., 2019. Floristic diversity with particular reference to endemic, rare, or endangered flora in forest formations of Saida (Algeria). International journal of Environment Studies, 1: 1-8. https: //doi.org/10.1080/00207233.2019.162054.

Dobignard A. \& Chatelain C., 2010-2013. Index synonymique de la Flore d'Afrique du Nord. Conservatoire et Jardin botaniques de la Ville de Genève $(\mathrm{CH})$, $5 \mathrm{Vol}$.

Gray P., 2005. Impacts of climate change on diversity in forested ecosystems: some examples. Forestry Chronicle, 81: 655-661. https//doi.org/10.5558/tfc 81655-5

Hamann A. \& Wang T., 2006. Potential effects of climate change on ecosystem and tree species distribution in British Columbia. Ecology, 87: 2773-2786. https://doi.org/10.1890/0012-9658 (2006) 87[2773: PEOCCO]2.0.CO;2

Hansen A.J. \& Dale V.H., 2001. Biodiversity in us forests under global climate change. Ecosystems, 4: 161163.

Hebda R., 1998. Atmospheric change, forests, and biodiversity. Environmental Monitoring and Assessment, 49: 195-212. https//doi.org/10.1023/ A:100 5869808440

Juday G.P., Duffy P., Linderhorm H., Rupp S., Sparrow S., Vaganov E. \& Yarie J., 2005. Forests, land management and agriculture. Arctic climate impact assessment: scientific report. Cambridge University Press, Cambridge, UK, pp. 781-854.

Kirschbaum M.U.F., 2000. Forest growth and species distribution in a changing climate. Tree Physiology, 20: 309-322.

Li C., Flannigan M.D. \& Corns I.G.W., 2000. Influence of potential climate change on forest landscape dynamics of west-central Alberta. Canadian Journal of Forest Research, 30: 1912. https//doi.org/10.1139/ cjfr-30-12-1905

Malcom J.R., Markham A., Neilson R.P. \& Garaci M., 2002. Estimated migration rates under scenarios of global climate change. Journal of Biogeography, 29: 835-849. https://doi.org/10.1046/j.1365-2699.2002. 00702.x

Maire R., 1952. Flore de l'Afrique du Nord (Maroc, Algérie, Tunisie, Tripolitaine, Cyrénaïque et Sahara). Lechevalier, Paris, $371 \mathrm{pp}$.

Mackenney D.W., Pedlar J.H., Campbell K. \& Hutchinson M.F., 2007. Potentiel impacts for climate change on the distribution of North Amerrican tree. Bioscience, 57: 939-948. https://doi.org/10.1641/B57 1106

Molinier R., 1934. Études phytosociologiques et écologiques en Provence Occidentale. Thèse Sc. Paris, 237 pp.

Olivier L., Muracciole M. \& Ruderon J.P., 1995. Premier bilan sur la flore des îles de la Méditerranée. Etat des connaissances et observations diagnostics et proposition relatifs aux flores insulaires de méditerranée par les participants au colloque d'Ajaccio. Corse. France (5-8 octobre, 1993) à l'occasion des débats et conclusions, pp. 356-358.

Quezel P. \& Santa S., 1962-1963. Nouvelle flore de l'Algérie et des régions désertiques méridionales. In CNRS (Ed). Paris, 2 vol., 1170 pp.

Quézel P., 1999. Biodiversité végétale des forêts méditerranéennes, son évolution éventuelle d'ici à trente ans. Forêt méditerranéenne, 20: 3-8.

S.A.T.E.C., 1976. Etude développement intégré de la daïra de Saida. Rapport technique, 93 pp.

Singh T. \& Wheaton E.E., 1991. Boreal forest sensitivity to global warming: implications for forest manage- 
ment in western interior Canada. Forestry Chronicle, 67: $1-348$

Thompson E.D., Flannigan M.D., Wotton B.M. \& Suffling R., 1998. The effects of climate change on landscape diversity: an example in Ontario forests. Environmental Monitoring and Assessment, 49: 213
233. https://doi.org/10.1023/A:1005894525278

Usher M.B., Callaghan T.V., Gilchrist G., Heal B., Juday G.P., Loeng H., Muir M.A.K. \& Prestrud P., 2005. Principles of Conserving the Arctic Biodiversity In Arctic Climate Impact Assessment, Cambridge University Press, London, pp. 539-596. 